Egyptian J. of Nutrition Vol. XXXVI No. 1 (2021)

\title{
Quality Assessment Of Potato Chips Packaged In Polypropylene Bags
}

\section{Nehad Mohamed Ibrahim 1, Yehia Abd El-Razik Heikal ${ }^{2}$, Mamdouh Helmi El-Kalyoubi ${ }^{2}$ and Khaled Sayed Nagy ${ }^{1}$}

1- Process Engineering and Packaging Dept., Food Tech. Res. Inst., Agric.

Res. Center, Giza. Egypt

2- Food Sci. Dept., Fac. Of Agric., Ain Shams Univ., P.O. Box 68 Hadayek Shoubra -11241, Cairo, Egypt

\begin{abstract}
The present work was designed to assess the quality of potato chips packaged in Biaxially Oriented Polypropylene (BOPP) Bags. Transparent and aluminated BOPP film were drawn on-line from a leading production company over a period of 5 months and subjected to physical and functional tests. Potato chips were fried in palm olein oil and filled in transparent and laminated BOPP-bags under nitrogen or atmospheric gas condition and stored at 3 different temperatures for 42 weeks. Atmosphere inside the bags was followed up for the change in $\mathrm{O}_{2}$ and $\mathrm{N}_{2}$ concentrations, while potato chips samples were subjected to moisture, peroxide value (PV) and microbial examinations.
\end{abstract}

Results reviled the presence of free spots on the surface of aluminated films, while tensile properties were in the range of 1136,2256 $\mathrm{kg} / \mathrm{cm}^{2}$ and an average seal strength of $118 \mathrm{gm} / \mathrm{cm}$. 


\section{Nehad Mohamed Ibrahim, Yehia Abd El-Razik Heikal, Mamdouh Helmi El-Kalyoubi and Khaled Sayed Nagy}

The average water vapor and oxygen transmission rates were $0.2 \mathrm{~g}$ $\mathrm{H}_{2} \mathrm{O} / \mathrm{m}^{2} . \mathrm{d}$ and $45 \mathrm{~cm}^{3} \mathrm{O}_{2} / \mathrm{m}^{2}$.d.bar, respectively. Assessment of oxygen concentration inside the metallized potato chips bags revealed that the atmosphere composition inside the bags comes in equilibrium with the surrounding atmosphere after 24 weeks of storage. The moisture content of potato chips increased from $1 \%$ at zero time to the level of $4-5 \%$ after 48 weeks of storage, while the Peroxide Value PV-value did not exceed 0.31 $\mathrm{mg} \mathrm{Eq} / \mathrm{kg}$ oil after 36 weeks of storage. The microbial analysis proved the absence of tested pathogenic bacteria, while the total bacterial count and number of yeast and molds remained under the values reported in the Egyptian Standard during the hole period of storage. It could be concluded that metallized and laminated BOPP bags are suitable for Packaging and for store the shelf life of potato chips ( 6 months) under the conditions that the potato chips are fried in palm olein oil and packaged under nitrogenatmosphere.

\section{Introduction}

Potato chips are the most popular snacks product because of their favourable crispy texture and flavor. Generally, snacks are described as a kind of food, which are usually eaten between meals. According to the statistical year book of Egypt (2017) and Market research (2020), the volume of snacks production from plant origin in Egypt reached 9.28 billion pounds (600 Million Dollars) out of total 130 billion pounds (8250 Million Dollars) for the whole sector of food industry. These Figures reflect the importance of snack industry, where potato chips represent more than $45 \%$ of this industry with annual growth of 19\% during the period 2014 to 2019 . Beside potato chips snacks of plant origin includes pretzels, nuts and seeds, popcorn, processed and extruded snacks, cookies, sweet biscuits as well as 


\section{Egyptian J. of Nutrition Vol. XXXVI No. 1 (2021)}

energy bars. Potato chips are thin potato slices $(<, 2 \mathrm{~mm})$ that are fried to remove moisture and decrease the water activity to around 0.2. During frying, the oil content increases to levels of $30-40 \%$. According to IUFOST (2020), the factor affecting deterioration of potato chips during storage are changes in texture because of increasing moisture content to level higher than $3.6 \%$ as well as rancidity due to oxidation of fats. The shelf life of potato chips depends on Packaging atmosphere, oxygen content, temperature, metal catalytic and light (Agrawal, et al.,(2018).

In Egypt, most of the industrial produced potato chips were packed in bi-axially oriented Polypropylene bags (BOPP) under nitrogen flushing.

A nitrogen atmosphere inside the package should decrease fat oxidation Kaur et al.,(2008).However, the protection function of nitrogen inside the bags did not last for a long period and the set up of oxidation and deterioration takes place and affecting the shelf life of the product. Several studies have been reported on the mode and reasons for potato chips deterioration. Robards et al.,(1988)applied head space analysis by gas chromatography - mass spectrometry to quantify volatiles formed in the oxidative deterioration of corn chips and found that the induction period (at $60^{\circ} \mathrm{C}$ ) for samples fried in palm olein oil was 59 days, while after that the oxidation was set up normally. Petukhov et al., (1999)studied the storage stability of potato chips fried in different types of canola oils and stored in 1.9 glass jars flushed with nitrogen. They found that potato chips developed an intense painty odor by the end of $16 \mathrm{~d}$ of storage, while those fried in hydrogenated canola oil had the lowest amount of total volatiles.

On other side, Pangloli et al., (2002)stated that potato chips fried in cottonseed and sunflower oils and stored in dark at $25^{\circ} \mathrm{C}$ for 6 weeks showed a peroxide valueof $3.4 \mathrm{meq} / \mathrm{kg}$, while mixing with palm olein oil at a 


\section{Nehad Mohamed Ibrahim, Yehia Abd El-Razik Heikal, Mamdouh Helmi El-Kalyoubi and Khaled Sayed Nagy}

level ratio of $40 \%$ reduced the PV-value to less than $1 \mathrm{meq} / \mathrm{kg}$. Potato chips stored under light experienced higher levels of peroxide values due to light induced fat oxidation.

Silva et al.,(2004),evaluated the influence of storage temperature and head space package atmosphere on the induction of lipid oxidation in packed potato chips. They found that potato crisps stored with an air atmosphere presented the lowest level of poly- unsaturated fatty acids, followed by those stored in nitrogen gas, while those samples stored with oxygen scavenger showed the lowest level of oxidation. They concluded that the use of a modified atmosphere is a good alternative for the shelf life improving. A nitrogen atmosphere inside the package decreased fatty acid changes only in the first month of storage. Shelf life of packages stored at 40 ${ }^{\circ} \mathrm{C}$ were much shorter due to accelerated liquid oxidation. Kaur et al.,(2013),reported that acrylamide was significantly reduced by decreasing frying temperature $<180^{\circ} \mathrm{C}$ and blanching pretreatment. Chips fried at 120 ${ }^{\circ} \mathrm{C}$ showed higher moisture retention compared with $150{ }^{\circ} \mathrm{C}$ and $180^{\circ} \mathrm{C}$. Blanching produced chips with relate. higher moisture content and lower oil uptake.

Saranya and Barathi (2012),fried potato chips in 6 different oils and packed them in Polypropylene bags and found that rancidity started in chips fried in palm oil after 34 days of storage, but chips fried in rice bran or in corn oil showed superior quality parameters during 45 days of storage.

On other side, Raheem (2013)stated that the barrier properties and capacity to protect foods depends largely on the permeability of the Packaging material to gases and vapors, while Polypropylene has a moderate barrier to moisture, gases and odors and orientation increases it's 
Egyptian J. of Nutrition Vol. XXXVI No. 1 (2021)

clarity, optical properties, tensile strength and resistance to puncture Allahvaisi,2012).Potato chips fried in mid-oleic sunflower oil, packaged in glass jars and stored for 6 weeks showed PV- values of 5 and $3 \mathrm{meq} / \mathrm{kg}$ when stored in dark or under fluorescent light, respectively (Lee and Pangloli, 2013).

Studies on the accelerated shelf life test of potato chips fried in canola oil and packed in transparent or metalized oriented Polypropylene bags flushed with nitrogen (Dunno, 2014),showed an increase in the oxygen concentration to $5 \%$, while the water activity of the chips samples was increased from 0.22 to 0.28 after 30 days of storage. Moisture content was also increased from 1.3 to a level of $2.4 \%$ and the crispness was also reduced from 1300 grams to 1000 grams during this period. Packages showed also pressure decay )loss of internal gas pressure) and increase in optical density of tested potato chips (increase in fat oxidation). For reducing the onset of rancidity, anti-oxidants could be added to the product formula or Packaging.

Vinothiniet al.,(2015)showed that potato chips fried in refined sunflower oil and packaged in polyester bags for 45 days has developed a PV-value of $37.75 \mathrm{meq} / \mathrm{kg}$, increase in moisture content from 1.16 to $1.4 \%$ and a microbial count of 526 CFU. Agarwal et al.,(2018)proved that nitrogen flushing of potato chips packaged in BOPP-bags has increased the shelf life of the product from 24 weeks to 32 weeks measured on the amount of Hexanal ( a product of oil oxidation) by using head space analysis and that the use of cheese or onion for seasoning could help extending the shelf life because of their anti-oxidative effect. The present work was designed to test the optical, mechanical, thermal and functional properties of locally produced biaxially oriented Polypropylene film and to assess the quality parameters of potato chips packaged in their bag. 


\section{Nehad Mohamed Ibrahim, Yehia Abd El-Razik Heikal, Mamdouh Helmi El-Kalyoubi and Khaled Sayed Nagy}

\section{Materials and Methods}

\section{Materials:}

Biaxially oriented Polypropylene (BOPP) films:

The films were obtained from a local producing company in Egypt. The BOPP films were produced by extrusion followed by longitudal (machine direction) and transvers stretching to get a clear thin film $(20 \mu \mathrm{m})$ with enhanced mechanical strength.

The produced thin films were covered on one side with Aluminum layer under a vacuum process using a fog of Aluminum to produce metallized single films and laminated with another printed transparent film to produce final films ready for food Packaging. Another run of transparent thin films were laminated with printed non- aluminated thin film to produce final transparent films (without Alumination) for Packaging purposes. Samples of the different films were monthly drawn from the production line over 5 months and subjected to quality tests at the laboratory.

\section{Potato chips:-}

The potato slices were washed to remove excess starch and fried continuously using palm oil olein at $180^{\circ} \mathrm{C}$ for approximately 6 minutes. The used palm olein oil was of zero PV and low free fatty acids content $(<0.05 \%)$. After frying, the chipsy were transported over a perforated conveyer to drain excess oil and drained from seasoned. Packaging was carried out automatically using vertical packaging machine. Transparent or Metallized, printed BOPP were used as packaging material. The packages were formed on line by side-sealing, followed by bottom sealing, filling and top sealing. Two different atmosphere were applied during Packaging: (Nitrogen or air atmosphere). Samples of Potato chips pages were obtained 
Egyptian J. of Nutrition Vol. XXXVI No. 1 (2021)

also from a leading producing company in Egypt.

All samples were stored in the laboratory under 3 different temperatures $\left(15-20^{\circ} \mathrm{C}\right) \cdot\left(30-35^{\circ} \mathrm{C}\right)$ and $\left(23-39^{\circ} \mathrm{C}\right.$ under day light) and stored for 36 week.

\section{Chemicals and Media:}

Calcium carbonate, acetic acid, chloroform, potassium iodide and thiosulfate were purchased from local chemical trading companies. All chemicals were of analytical purity grad .Nutrient agar media, potato agar and dextrose media, maconcy media, tri sugar iron (T.S.I) were purchased from specified supplying companies, Cairo, Egypt. The media were used for determining total count, yeasts and molds, coliform group, salmonella\& shigella.

\section{Methods:}

\section{1-Thickness and Optical properties ofBOPP-films:}

The thickness of the film was measured in micron units by a digital micrometer device (Mitutoyo, Japan) according to the method described by Teixeira, et al.,(2017).Microscopic observation of metalized BOPP surfaces was made by the use of an optical microscope (S04-600X Digital microscope). Treated met-Bopp samples with dimensions 360 * $360 \mathrm{~mm}^{2}$ were examined. The used microscope magnification power was 100 times. The light transmission of transparent and metallized Bopp films was measured using the LS 108 spectrum transmission meter (LS Telecom AG, Germany). The device is a blue - violet tester for plastic films at $430 \mathrm{~nm}$ and $395 \mathrm{~mm}$. Purple light source, blue light source and a visible light source were used to illuminate the tested material (BOPP films). The weight of aluminum layer was measured by the difference in weight of aluminated and transparent BOPP films as described in ISO 2286 (2016), using 
Nehad Mohamed Ibrahim, Yehia Abd El-Razik Heikal, Mamdouh Helmi El-Kalyoubi and Khaled Sayed Nagy

analytical balance (Mettler Toledo PB 102, Switzerland) and the difference was calculated in $\mathrm{mg} / \mathrm{m}^{2}$.I

\section{2- Mechanical and ThermalProperties:}

Tensile strength

The tensile strength was measured by a universal testing machine (Brookfield CT3 Texture Analyzer, Cleveland, Ohio, USA), equipped with a $5 \mathrm{~kg}$ load cell according to ASTM (1987e) -D- 882-83.Film strip in dimension of $50^{*} 10 \mathrm{~mm}$ and free from air bubbles or physical imperfections were held between clamps positioned at a distance of $3 \mathrm{~cm}$. Thickness of the test strip was chicked prior to testing. During measurement, the strips were pulled by the top clamp at a rate of $2.0 \mathrm{~mm} / \mathrm{s}$ to a distance of $10 \mathrm{~cm}$ for BOPP films before returning to the starting point. The force was measured when the film broke. Tensile stress and tensile strain were given in $\left(\mathrm{kg} / \mathrm{cm}^{2}\right.$ and in \%), respectively.

\section{Heat seal temperature and seal strength:}

The heat seal temperature: A heat sealing equipment (Pressto heat sealer, Testing instruments manufacturing company, India) was used for testing the heat seal temperature of BOPP-film.The pressure of the bars was fixed at 2 bar and dwell time was fixed at 1 second. The seal was performed at different temperatures between $120-135{ }^{\circ} \mathrm{C}$. After each seal trial, the seal strengthwas measured and the temperature at which the maximum seal strength was achieved is considered as seal temperature. Seal strength was measured according to the standard method ASTM F88 (1987)with rectangular samples of a sealed film in a dimension of $15 \mathrm{~mm}$ width and $250 \mathrm{~mm}$ length. 
Egyptian J. of Nutrition Vol. XXXVI No. 1 (2021)

The film strip was placed through two free ends in the clamps of the Brookfield Texture Analyzer (CT3) and the force necessary to peel apart the two pieces of film strip is then measured at a moving speed of $300 \mathrm{~mm} / \mathrm{min}$.

\section{3- Functional properties of BOPPfilm:-}

The water vapor transmission rate (WVTR) of BOPP films was tested as described in ASTM (1987) / D - 895and carried out by tightly sealing the top of cup, containing water at ambient temperature, by the specimen of the tested BOPP film. The cup was weighted initially and then at regular intervals, where the losses in weight $m_{v}$ was measured and the water vapor transmission rate (WVTR) was calculated and given in $\mathrm{g} \mathrm{HzO} / \mathrm{m}^{2} . \mathrm{d}$. The water vapor permeability (WVP) was calculated according to the following equation:

WVP $=\frac{W V T R}{P S(R H 1-R H 2)}$ in $\left(\mathrm{g} \mathrm{H} \mathrm{H} / \mathrm{m}^{2}\right.$. d.mm Hg), where $\mathrm{RH}_{1}, \mathrm{RH}_{2}=$ Relative humidity on the both side of the film and $P_{s}=$ the saturated water vapor pressure at $25^{\circ} \mathrm{C}$ (in $\mathrm{mm} \mathrm{Hg}$ ).

The oxygen permeability was measured according to the method of International Organization for Standardization (2010)as described in ISO number 15105. A systech Illinois equipment was used for the Oxygen permeability test (systech Illinois m8500; Advanced Technology in Oxygen Permeability Measurement, USA).The oxygen transmission rate (OTR) was displayed in $\mathrm{cm}^{3} \mathrm{O}_{2} / \mathrm{m}^{2}$.day. The used film sample size was $50 \mathrm{~cm}^{2}$.

\section{4-Analysis methods for the potatochips}

Measuring (Tracing) oxygen concentration inside bags: The oxygen, carbon dioxide, and nitrogen concentration inside the bags of potato chips was followed up during the storage period. The $\mathrm{O}_{2}$ and $\mathrm{Co}_{2}$ 
Nehad Mohamed Ibrahim, Yehia Abd El-Razik Heikal, Mamdouh Helmi El-Kalyoubi and Khaled Sayed Nagy

concentrations were measured by a portable gas analyzer (OXYBABY 6, WITT- Gas technik Gmbh, Witten, Germany, according to the Method described by Esmer, et al,.(2011).

Moisture Content of Potato chips: The moisture content was analyzed by near infrared moisture meters (Type Axis, Model AGS 50/IR, Gdansk, Poland) according to Bradley (2010). A 0.5 gram of crushed sample was weight using a digital analytical balance (Mettler Toledo PB 102, Switzerland). The test sample was placed on aluminum pan and heated under control program with a heating range of $110-180{ }^{\circ} \mathrm{C}$ using the infrared heating device.

Instrument automatically weight and calculates the percentage moisture content and give it on the display. The result could be obtained within 7-15 min.

Tracking peroxide value of Potato Chips and Popcorn: Peroxide value was determined according to the standard method AOAC (2000)and expressed as $\mathrm{mg} \mathrm{Eq} / \mathrm{kg}$ oil.

\section{Preparation of test samples for microbial analysis:}

Twenty five gram of crushed samples of Chips or popcorn were added to $225 \mathrm{ml}$ of pepton water in a beaker and mixed well at a speed of 15 to 20 * $10^{3} \mathrm{rpm}$ for 2-3 minute.

The mixture was diluted twice by taking $1 \mathrm{ml}$ from the mixture to $9 \mathrm{ml}$ of pepton water (1.dilution) and $1 \mathrm{ml}$ from 1.dilution to $9 \mathrm{ml}$ of pepton water (2.dilution). The prepared suspensions of potato chips was used for the microbial analysis. Total Count: Total Count was determined according to ISO - 4833 -1(2013). Yeasts and molds: Yeasts and molds were 
Egyptian J. of Nutrition Vol. XXXVI No. 1 (2021)

determined according to ISO 21527-2 (2013). Coliform group:Coliform group was determined according to ISO - 4832 (2006). Salmonella and Shigella: Salmonella and Shigella were determined according to the method applied by Ahmed et al.,(2020).

Statistical analysis: All experiments were carried out in 3 replicates at least. Average and standard deviation were calculated. The significancy level between means of the obtained data was examined by analysis of variance using ANOVA one way analysis using statistical system (SPSS, 2006).Significance level was carried out by Duncan multiple range test at a level of $\mathrm{P}<0.05$.

\section{Results and Discussion}

The aim of the present work was to evaluate the suitability of BOPPfilms to maintain the quality of potato chips packaged in their bags. Therefore, the results will include the technological characteristics of BOPPfilm and the assessment of packed chips quality during the storage time.

\section{1- Surface characteristics of BOPP-films:}

Table (1) shows the surface quality of BOPP-film such as thickness of transparent as well as aluminated films and their optical density. As seen, the average thickness of BOPP-film used in formation of potato chips bags was 20.2 micron. The thickness value was increased by about 3 micron through the alumination process, while lamination of the aluminated film with an another layer of printed BOPP-film raised the total thickness to 45-46 micron, with no significant differences within and between the film samples drawn over 5 months of production, which ensure the stability of the produced film for the manufactures and for the packers. The obtained 
Nehad Mohamed Ibrahim, Yehia Abd El-Razik Heikal, Mamdouh Helmi El-Kalyoubi and Khaled Sayed Nagy

thickness values of BOPP-film agree with those of Gajdaset al.,(2000) ;Meller et al.,(2012)and Du et al.,(2015).The weight of aluminum layer was $214.8 \mathrm{mg} / \mathrm{m}^{2}$, which agree with the values reported by Lazicet al.,(2010), Simseker (2012)and MECI (2015) for a standard alumination of $0.05 \mu \mathrm{m}$ thickness.

The quality of the alumination process could be assessed through detection of uncovered spots by microscopic examination and by measuring the light transparency through spectrophotometric test. Data in Figure (1) shows the presence of white uncovered spots in spite of the relatively sufficient weight of aluminum layer, which could be referred to technical problems in the vacuum alumination process.

According to Marra (1988), the variation in the thickness of the aluminum layer could be referred to the inhomogeneity of surface energy applied during alumination, which should increase the surface resistance of the produced film to the range of $2 \mathrm{Ohm} / \mathrm{m}^{2}$. However, the light transparency of the BOPP films were reduced from $88.3 \%$ for the transparent film to the level of $1.5 \%$ after alumination as seen in Table (1). According to Rahmatollahpuret al.,(2010), dust on the substrate (BOPPfilm) is the main factor on the formation of pinholes in the aluminum layer, which prohibits the formation of aluminum on these locations.

\section{2- Mechanical, thermal and barrier properties of BOPP-film:-}

Table (2) shows the mechanical and functional properties of the tested BOPP-films. They include tensile stress in longtidual Machine direction(MD) and Transvers direction (TD), heat seal temperature and strength as well as water vapor and oxygen permeability. As seen, the average tensile stress of the transparent films was $1130 \mathrm{~kg} / \mathrm{m}^{2}$ in longtidual 


\section{Egyptian J. of Nutrition Vol. XXXVI No. 1 (2021)}

direction and $2230 \mathrm{~kg} / \mathrm{m}^{2}$ in transvers direction. Metallization induced a little enhancement in the tensile stress value and raised it to the level of 1136 and $2256 \mathrm{~kg} / \mathrm{m}^{2}$, respectively. Generally, the tensile strength values in the transvers (TD) direction were almost double that of the longtidual (MD) direction. The obtained results agree with those of MarDruk(2009) ,Vassiliadi (2007) and $\mathrm{MECl}$ (2015), where stress values for BOPP films in the level of 1200 and $2700 \mathrm{~kg} / \mathrm{m}^{2}$, respectively for (MD) and (TD) test were reported.

Heat seal is formed by bonding together two polymer surfaces in the way that the surfaces are forced into intimate contact while they are in molten state. As seen in Table (2), the test of heat seal temperature was carried out for BOPP-film samples obtained over 5 months from the producer. As seen, the average heat seal temperature of the transparent films was $132.8^{\circ} \mathrm{C}$ with significant differences between the samples drawn over the 5 months period. Heat seal temperature for the metallized films was slightly increased to the level of $133.8^{\circ} \mathrm{C}$. According to Farris et al.,(2009)bar temperature and pressure are of primary importance that affecting the seal temperature and strength.

The seal strength is defined as the maximal force required to separate a heat seal during a tensile test, in which the seal region is placed in the middle of test specimen. The average value for seal strength of transparent and metalized BOPP-films were 181.4 and $171.4 \mathrm{~g} / \mathrm{cm}(2.66$ and $2.52 \mathrm{~N} / 15 \mathrm{~mm}$ ), respectively. Printing reduced also the seal strength to the value of average $117.6 \mathrm{~g} / \mathrm{cm}(1.73 \mathrm{~N} / 15 \mathrm{~mm})$. According to the specification of MarDruk(2009), Du et al.,(2020) and MECl (2015), the heat seal strength for transparent 20 micron BOPP-film should be in the range of 2.2 to $2.3 \mathrm{~N} / 15 \mathrm{~mm}$. On other side, published a test procedure for heat seal strength of laminates and reported that the maximum strength 
Nehad Mohamed Ibrahim, Yehia Abd El-Razik Heikal, Mamdouh Helmi El-Kalyoubi and Khaled Sayed Nagy

must be at least $1.5 \mathrm{~N} / 15 \mathrm{~mm}$ (width) in compliance with European standard (EN 868-5). Sealing strength of laminated and printed BOPP metalized composite was reduced to the level of $120 \mathrm{~g} / \mathrm{cm}(1.76 \mathrm{~N} / 15 \mathrm{~mm})$, which is relatively lower than the limit of $2.2 \mathrm{~N} / 15 \mathrm{~mm}$ reported above.

Table (2) shows also the values for water vapor and oxygen permeability. As seen, the water vapor permeability of the transparent BOPP-film was very high with an average of $8.04 \mathrm{~g} \mathrm{H}_{2} \mathrm{O} / \mathrm{m}^{2}$.d. This value was reduced to the level of $4.54 \mathrm{~g} \mathrm{H}_{2} \mathrm{O} / \mathrm{m}^{2}$.d for printed film. Metalization did drastically reduce the water vapor permeability level to $0.84 \mathrm{~g} \mathrm{H}_{2} \mathrm{O}$ $/ \mathrm{m}^{2}$.d, while lamination of printed and metalized films reduced the water vapor permeability to the level of only $0.18 \mathrm{~g} \mathrm{H}_{2} \mathrm{O} / \mathrm{m}^{2}$.d. The obtained results agree with those of Khalifa (2016)as well as Adjoumanet al.,(2017).They reported values for water vapor permeability ranging between 1.85 to $6.2 \mathrm{~g} \mathrm{H}_{2} \mathrm{O} / \mathrm{m}^{2}$.d for transparent BOPP-films according to their thickness, metalization and lamination. According to ASTM standard (N.1249), flexible films were classified as high barrier for $\mathrm{H}_{2} \mathrm{O}$ if the permeability values were in the range of $1 \mathrm{~g} \mathrm{H}_{2} \mathrm{O} / \mathrm{m}^{2}$.d. According to this classification the obtained BOPP films in the present work could be considered as high barrier, since the average permeability value was reduced to $0.18 \mathrm{~g} \mathrm{H}_{2} \mathrm{O} / \mathrm{m}^{2}$.d.

\section{Oxygen permeability Characteristics of tested BOPP films:}

As seen, in Table (2), the values of oxygen permeability measured for samples drown over 5 months were very close to each other indicating the stability and constancy in the produced films. For the transparent BOPP film, the average values for the oxygen transferee ratio was $1864 \mathrm{~cm}^{3}$ $\mathrm{O}_{2} / \mathrm{m}^{2}$.day.bar. This permeation values are relatively higher than those reported By Lazic.etal,. (2010)(1130.8 $\mathrm{cm}^{3} \mathrm{O}_{2} / \mathrm{m}^{2}$.day bar) may be due to 


\section{Egyptian J. of Nutrition Vol. XXXVI No. 1 (2021)}

the difference in the thickness of the used Bopp- film (40 $\mu \mathrm{m}$ versus $20 \mu \mathrm{m})$. According to, Mueller.etal,. (2012), permeability of the uncoated transparent BOPP films ranges from 800 to $1000 \mathrm{~cm}^{3} \mathrm{O}_{2} / \mathrm{m}^{2}$.d.bar, when the thickness of the film was increased from 20 micron to 40 micron.

Metallization of the transparent BOPP film with a monolayer of aluminum reduced the permeability level of $\mathrm{O}_{2}$ to the range of 144 $\mathrm{cm}^{3} \mathrm{O}_{2} / \mathrm{m}^{2}$.day.bar. The permeability of the metalized film represent 0.077 to 0.09 that of the transparent film. According to Lazi. et al., (2010) and Mueller.et al,. (2012), lamination process improves the oxygen barrier but not necessarily the moisture barrier as there are different mechanisms for $\mathrm{O}_{2}$ and moisture permeability. Metalizing although prevents light from entering because light is a catalyst for the oxidation of fat.

As seen in Table (2), lamination of two unmetalized transparent printed films reduced the oxygen permeability level to 480 - 489 $\mathrm{cm}^{3} \mathrm{O}_{2} / \mathrm{m}^{2}$.day .bar, which is also higher than the safe level. The permeability rate of $\mathrm{O}_{2}$ was drastically reduced to the level of only $47 \mathrm{~cm}^{3}$ $\mathrm{O}_{2} / \mathrm{m}^{2}$ day.bar recorded for the laminated metalized BOPP films. The result proved that the quality of metallization process and metalized layer play a great role in the permeability level of $\mathrm{O}_{2}$. The obtained $\mathrm{O}_{2}$ barrier characteristic of laminated BOPP films agree with these reported by lazic et al, 2010 (44.6 $\mathrm{cm}^{3} \mathrm{O}_{2} / \mathrm{m}^{2}$.day.bar), which indicate that the tested laminated films meet the standard for the BOPP films. The effect of printing on the barrier properties of BOPP-films was investigated by Khalifa(2016).Printing material had the positive impact on the barrier properties of the laminated film, since the permeability ratio for oxygen was reduced to the level of $42 \mathrm{~cm}^{3} \mathrm{O}_{2} / \mathrm{m}^{2}$.day.bar. 
Nehad Mohamed Ibrahim, Yehia Abd El-Razik Heikal, Mamdouh Helmi El-Kalyoubi and Khaled Sayed Nagy

\section{3- Quality assessment of potato chips packed in BOPP-bags Gascomposition}

As discussed before, biaxially oriented PP showed the most suitable morphological, mechanical and functional properties for packaging. For this purpose, metalized laminated BOPP films were formed in pages of about $600 \mathrm{~cm}^{3}$ volume, filled with fried potato chips under neutral atmosphere (air) or under nitrogen injection. The packages were assessed for functionality of the package and quality of food snacks for a period up to 44 weeks. Table (3) shows the results of changes recorded in $\mathrm{O}_{2}, \mathrm{~N}_{2}$ and $\mathrm{CO}_{2}$ concentration in chips bags during the period of storage. Values were assessed for bags during winter season, (average temperature $25^{\circ} \mathrm{C}$ ), summer season (room temperature in therange of $30-35^{\circ} \mathrm{C}$ ) as well as for bags stored outside on the roof of the laboratorybuilding.

As seen, the initial atmosphere composition inside the bags consists of $98 \%$ nitrogen, $2 \%$ oxygen and zero percent of carbon dioxide. During winter season the chips bags reached the level of $80 \%$ nitrogen, $19 \%$ oxygen and ; $1 \%$ carbon dioxide ( almost normal atmosphere components ) after 14 weeks (98 day) of storage (in dark) inside the laboratory rooms. In summer time, the atmospheric composition of gas atmosphere inside the bags reached an equilibrium with the surrounding atmosphere after only 10 weeks of storage (70 days). On other side, chips bags sample stored on the roof reached equilibrium after only 6 weeks (42 days).

Based on the permeability characteristics of oxygen given in Table (2), $\left(480 \mathrm{~cm}^{3} \mathrm{O}_{2} / \mathrm{m}^{2}\right.$.day.bar), the amount of oxygen penetrated to the bag was very high during the first four weeks and these amount were gradually decreased thereafter due to the changing oxygen pressure difference between outside and inside atmosphere. Taking in consideration that bags 


\section{Egyptian J. of Nutrition Vol. XXXVI No. 1 (2021)}

has a surface area of $550 \mathrm{~cm}^{2}$ and a volume of $600 \mathrm{~cm}^{3}$, calculations showed that the total amounts of oxygen penetrated through the transparent BOPP bags reached $226 \mathrm{~cm}^{3} \mathrm{O}_{2}$ after 12 weeks and $300 \mathrm{~cm}^{3} \mathrm{O}_{2}$ after16 weeks of storage, weighing $0.323 \mathrm{~g} \mathrm{O} 2$ and $0.430 \mathrm{~g} \mathrm{O}_{2}$ representing a weight/volume ratio of $0.054 \%$ and $0.072 \%$, respectively. This ratio is 14 and 11 times higher than the allowed $\mathrm{O}_{2}$ ratio of $0.005 \%$ (Valentas et al.,1997, and Khalifa 2016). For packaging and storage of potato chips in metalized and laminated BOPP-bags, the potato chips were prepared as mentioned before and packed under nitrogen atmosphere and the gas composition inside the packs was assessed for 24 weeks for bags stored under winter, summer or outside temperature and light conditions, and the result are given in Table(3). As seen, it took 24 weeks (168 day) for the gas atmosphere inside the bags to reach equilibrium with the surrounding atmosphere. The concentration of gas inside the pack started with only $2 \%$ and reached $19 \%$ after 24 weeks due the penetration of $\mathrm{O}_{2}$ from the surrounding atmosphere. Similar trend was also observed for potato chips packed and stored under summer temperature conditions but the equilibrium was achieved in only 20 weeks instead of 24 weeks. This means, that it took shorter time in sumer season compared with it that winter season.

On other side, potato chips bags stored outside under high temperature and light reached the equilibrium after only 18 weeks. The amount of oxygen penetrated inside the metalized BOPP packs is about 45 $\mathrm{cm}^{3}$ over the 24 weeks of storage indicating the capacity of the aluminum layer to withstand and prevent oxygen from penetration through the BOPP bags and reduce the rancidity level of the stored potato chips. However, the weight/volume ratio of $\mathrm{O}_{2}$ inside the bags reached $0.01 \%$ which is double that of the maximum allowed ratio $(0.005 \%)$. 
Nehad Mohamed Ibrahim, Yehia Abd El-Razik Heikal, Mamdouh Helmi El-Kalyoubi and Khaled Sayed Nagy

\section{Moisture content and peroxide values of potato chips during storage}

The quality characteristics of the packed fresh potato chips were as follows (moisture content $1 \%$ on dry weight base) and peroxide number value of zero (as $\mathrm{ml} \mathrm{Eq}$ olic acid/ $\mathrm{kg}$ ). Concerning the migration of moisture to inside the transparent chips bags, Table (4) shows that the moisture content of the chips sample was increased to 2.4 and 2.9 after 16 weeks of storage and then increased to the level of 4 to $5 \%$ after 32 weeks for chips bags filled under nitrogen atmosphere and stored respectively under winter, summer, and outside conditions. According to the Egyptian standard ES:1629 (2017), the maximum moisture content of potato chips should not allowed to exceed $3 \%$. These specification could be maintained for 16 weeks in winter, 20 weeks in summer and 18 weeks under outside condition. The amount of migrated $\mathrm{H}_{2} \mathrm{O}$ indicate that the moisture content of potato chips required longer time in summer than in winter season to reach the limit.

The change in moisture content of potato chips packed in metallized BOPP-bags and stored under nitrogen gas conditions are also given in table (4). As seen, the moisture content reached a level of 2.2 to $2.3 \mathrm{gmH}_{2} \mathrm{O} / 100$ gm potato chips after 44 weeks ( 300 day) of storage under winter, summer or outside conditions. This means, that the potato chips remained crispy during the 44 weeks storage under nitrogen gas atmosphere according to the Egyptian stander ES:1629(2017). Extending the storage time to 48 weeks caused a rapid increase in moisture content of potato chips to reach level of $4 \%$ and $5 \%$.

The peroxide value was assessed for potato chips packaged in transparent BOPP bags under nitrogen gas and under normal atmospheric air and the results are given in Table (5). As seen, the incubation period of 


\section{Egyptian J. of Nutrition Vol. XXXVI No. 1 (2021)}

the chips fat lasted for only 4 weeks (28 day). For winter season, the PV value reached only $0.16 \mathrm{ml} \mathrm{Eq} / \mathrm{kg}$ oil, while those stored under summer condition or outside showed more rancidity values and PV reached $0.2 \mathrm{ml} /$ Ekg oil after 16weeks (112 day). On other side, potato chips bags stored under atmospheric air condition showed an incubation period of less than 4 weeks (28 day). The level of PV values reached 0.51 to $0.65 \mathrm{ml} / \mathrm{Ekg}$, oil after 16 week of storage. As seen in Table (5),the peroxide values of potato chips sample were lower than the limit reported in the Egyptian standard (ES:1629,2017, 10\%). The reason for this lower value of PV could be referred to the type of oil used in potato frying. (Palm oil which is known to be consisting of saturated oils and only $44 \%$ of mono unsaturated olice acid).

Published researches showed that Potato chips fried in cotton seed oil or sunflower oil and packed in BOPP-bags reached PVvalues higher than $10 \mathrm{mg} \mathrm{Eq} / \mathrm{kg}$.oil due to the high ratio of unsaturated fatty acid in these oils. (Rade et al.,1997 and Goekmen,2004).

As seen in Table(5), the incubation period for fats in potato chips stored in metalized laminated BOPP was extended to a period up to 12 weeks for samples stored under nitrogen gas atmosphere in winter and summer season, while the peroxide value were slowly increased to the level of 0.18 to $0.21 \mathrm{ml} \mathrm{Eq} / \mathrm{kg}$ oil after 36 weeks of storage. However, potato chips samples stored under outside and light conditions showed lower incubation period (4 weeks) and higher PV values reached after 36 weeks $(0.31 \mathrm{ml} / \mathrm{Ekg}$.oil). On contrary, potato chips sample stored under atmospheric gas conditions showed shorter induction time (4 weeks) and relatively higher PV values ( 0.6 to $0.88 \mathrm{ml} / \mathrm{Ekg}$.oil) after 36 weeks of storage. The recorded PV values were much lower than those reported in the Egyptian stander ES: 1629(2017) due the use of palm oil as discussed before. 
Nehad Mohamed Ibrahim, Yehia Abd El-Razik Heikal, Mamdouh Helmi El-Kalyoubi and Khaled Sayed Nagy

\section{3: Microbiological quality of packed potato chips during storage:-}

Contamination of potato chips can occur during harvesting, cleaning, peeling, slicing and Packaging of potato tubers and chips. Table(6) shows the results of microbial examination for potato chips packed in transparent or metalized BOPP-bags and stored for different periods under different conditions.

As seen, potato chips packed under nitrogen flushing or under atmosphere air inside the bags showed zero bacterial count, yeast and molds. Transparent chips bags stored under nitrogen flushing showed no growth of bacteria for 8 weeks. However, bags stored under outside conditions showed a slight growth (8 CFU after 12 weeks of storage, while those stored inside laboratory under winter or summer temperature conditions showed a slight growth (5 CFU) after 16 weeks of storage for samples stored under nitrogen flushing. On other side, samples stored under atmospheric condition inside the bags showed greatial growth already after 8 weeks $(5 \mathrm{CFU}$ ) and the growth reached $15 \mathrm{CFU}$ after 16 weeks. The microbial growth could be correlated with the oxygen and moisture ratio inside the bags during storage. Concerning the count of yeast and molds, the bags stored under nitrogen flushing remained free for 12 weeks from yeast and molds and the count reached 5-10 CFU thereafter. Samples stored under atmospheric conditions showed yeast and molds growth already after 8 weeks and the number reached 10-15 CFU after 20 weeks ofstorage.

Potato chips samples packed in metalized BOPP-bags showed microbial safety for 24 weeks and the bacterial growth was increased thereafter to reach 10-20 CFU after 36 weeks of storage. According to the obtained results in Table (6Samples stored under atmospheric conditions 
Egyptian J. of Nutrition Vol. XXXVI No. 1 (2021)

showed bacterial safety for only 16 weeks and the growth reached 15 to 20 CFU after 36 weeks of storage.

For yeast and molds, the growth started first after 28 weeks for samples stored under nitrogen flushing and after 20 weeks for those stored under atmospheric conditions.

The number of yeast and molds reached values of 8 to 16 CFU after 36 weeks of storage.Tracking pathogenic bacteria (salmonella \& shigella) and coliform group showed no growth of such bacteria during the whole of storage period, either in chips samples stored in transparent or metalized BOPP-bags. This hazard could be excluded from potato chips samples tested under the aforementioned laboratory conditions. According to the Egyptian specifications for potato chips (ES:1629/2017), the microbiological load of the tested potato chips samples still in the safe limits, since the number of bacterial count should not exceeded $5 \times 10^{4} \mathrm{CFU}$ and the number of coliform groups should not exceeded $10 \mathrm{CFU} / \mathrm{gm}$.

\section{Conclusion}

The most important factor in determining the functionality of BOPP sheets is not the thickness, but the quality and integrity of the aluminum layer. In transparent BOPP-bags, the protecting effect of nitrogen gas lasts for only 12 weeks during storage, because the inside atmosphere approaches the outside atmosphere after this period of storage. Rancidity values of potato chips packed in metalized BOPP-bags under nitrogen atmosphere after 36 weeks was still under the limits allowed in the corresponding Egyptian standard. The packed potato chips were free from pathogenic contamination as well as yeasts and molds during the first 24 weeks of storage. 
Nehad Mohamed Ibrahim, Yehia Abd El-Razik Heikal, Mamdouh Helmi El-Kalyoubi and Khaled Sayed Nagy

The recommended aluminum layer for BOPP-sheets used in Packaging potato chips fried in palm oil olein should not under $165 \mathrm{mg} / \mathrm{m}^{2}$. Based on the obtained results, a safe shelf life of potato chips (6 months) fried in different oils, including unsaturated oils requires the following specifications in the BOPP-packaging materials:

The weight of the aluminum layer should be not lower than $200 \mathrm{mg} / \mathrm{m}^{2}$; a transparency value between 1.1 to $1.8 \mathrm{OD}$; a heat seal temperature in the range of $136^{\circ} \mathrm{C}$, a water vapor permeability value in the range of 0.16 to 0.2 $\mathrm{g} \mathrm{Hzo} / \mathrm{m}^{2} . \mathrm{d}$ and an oxygen transmission rate between 45 to $50 \mathrm{~cm}^{3} \mathrm{O}_{2} / \mathrm{m}^{2}$.d. 
Egyptian J. of Nutrition Vol. XXXVI No. 1 (2021)

Table1. Thickness and optical density of BOPP films

\begin{tabular}{c|c|c|c|c}
\hline \multirow{2}{*}{$\begin{array}{c}\text { Month of } \\
\text { sample draw }\end{array}$} & \multicolumn{4}{|c}{ Thickness(micron) } \\
\cline { 2 - 5 } & Transparent & Metalized & $\begin{array}{r}\text { Transparent } \\
\text { printed }\end{array}$ & $\begin{array}{r}\text { Metalized } \\
\text { printed }\end{array}$ \\
\hline 1 & $20^{\mathrm{a}} \pm 1$ & $24^{\mathrm{a}} \pm 1$ & $45^{\mathrm{a}} \pm 1$ & $47^{\mathrm{a}} \pm 1$ \\
\hline 3 & $21^{\mathrm{a}} \pm 1$ & $24^{\mathrm{a}} \pm 1$ & $46^{\mathrm{a}} \pm 1$ & $47^{\mathrm{a}} \pm 1$ \\
\hline 4 & $20^{\mathrm{a}} \pm 0$ & $23^{\mathrm{a}} \pm 1$ & $45^{\mathrm{a}} \pm 1$ & $46^{\mathrm{a}} \pm 1$ \\
\hline 5 & $20^{\mathrm{a}} \pm 1$ & $24^{\mathrm{a}} \pm 1$ & $45^{\mathrm{a}} \pm 1$ & $47^{\mathrm{a}} \pm 1$ \\
\hline & $20^{\mathrm{a}} \pm 1$ & $24^{\mathrm{a}} \pm 1$ & $46^{\mathrm{a}} \pm 1$ & $47^{\mathrm{a}} \pm 1$ \\
\hline
\end{tabular}

\section{Count.Table1.}

\begin{tabular}{|c|c|c|c|c|}
\hline \multicolumn{2}{|c|}{ Aluminum layer } & \multicolumn{3}{|c|}{$\begin{array}{c}\text { Transparency \% at } \\
\text { wave length }\end{array}$} \\
\hline $\begin{array}{c}\text { Thickness } \\
(\mathrm{mm})\end{array}$ & $\begin{array}{r}\text { Weight } \\
\mathrm{mg} / \mathrm{m}^{2}\end{array}$ & $\begin{array}{l}395 \\
\mathrm{~nm}\end{array}$ & $\begin{array}{l}430 \\
\mathrm{~nm}\end{array}$ & $\begin{array}{l}55 \\
\mathrm{~nm}\end{array}$ \\
\hline \multirow{2}{*}{$4^{a} \pm 1$} & \multirow{2}{*}{$220^{b} \pm 2$} & \multicolumn{3}{|c|}{ Transparent } \\
\hline & & 86.2 & 88.9 & 89.8 \\
\hline $3^{a} \pm 0$ & $225^{a} \pm 1$ & \multirow{2}{*}{\multicolumn{3}{|c|}{ Metalized }} \\
\hline $3^{a} \pm 1$ & $195^{d} \pm 1$ & & & \\
\hline $4^{a} \pm 1$ & $218^{\mathrm{bc}} \pm 1$ & 1.8 & 1.6 & 1.1 \\
\hline $4^{a} \pm 1$ & $216^{c} \pm 1$ & & & \\
\hline
\end{tabular}

Means followed by different small letters in the same row (effect of time) are significantly different by Duncan's multiple test $(P<0.05)$ 
Nehad Mohamed Ibrahim, Yehia Abd El-Razik Heikal, Mamdouh Helmi El-Kalyoubi and Khaled Sayed Nagy

Table 2. Mechanical, Thermal and Functional properties of BOPP films

\begin{tabular}{|c|c|c|c|c|c|c|c|c|}
\hline \multirow{3}{*}{ 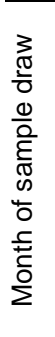 } & \multicolumn{4}{|c|}{ Tensile Strength $\left(\mathrm{kg} / \mathrm{cm}^{2}\right)$} & \multirow{2}{*}{\multicolumn{4}{|c|}{ Heat seal temperature $(\mathrm{C})$}} \\
\hline & \multicolumn{2}{|c|}{$\begin{array}{l}\text { Before } \\
\text { metalized }\end{array}$} & \multicolumn{2}{|c|}{$\begin{array}{l}\text { After } \\
\text { metalized }\end{array}$} & & & & \\
\hline & $\begin{array}{l}\mathrm{MD} \\
\times 10\end{array}$ & $\begin{array}{l}\text { TD } \\
\times 10\end{array}$ & $\begin{array}{l}\mathrm{MD} \\
\times 10\end{array}$ & $\begin{array}{l}\text { TD } \\
\times 10\end{array}$ & 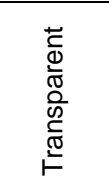 & $\begin{array}{l}\overline{8} \\
\frac{N}{\bar{N}} \\
\frac{\pi}{0} \\
\sum\end{array}$ & 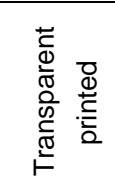 & 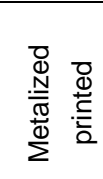 \\
\hline 1 & $114^{\mathrm{ab}} \pm 1$ & $228^{a} \pm 1$ & $115^{\mathrm{ab}} \pm 1$ & $229^{a} \pm 1$ & $135^{a} \pm 1$ & $135^{\mathrm{a}} \pm 1$ & $136^{a} \pm 1$ & $136^{\mathrm{a}} \pm 1$ \\
\hline 2 & $115^{a} \pm 1$ & $226^{\mathrm{b}} \pm 1$ & $116^{a} \pm 1$ & $220^{\mathrm{a}} \pm 1$ & $134^{\mathrm{ab}} \pm 1$ & $135^{\mathrm{a}} \pm 1$ & $135^{\mathrm{ab}} \pm 1$ & $135^{\mathrm{a}} \pm 1$ \\
\hline 3 & $113^{\mathrm{bc}} \pm 1$ & $225^{b} \pm 1$ & $115^{\mathrm{ab}} \pm 1$ & $226^{a} \pm 1$ & $133^{\mathrm{bc}} \pm 1$ & $134^{\mathrm{ab}} \pm 1$ & $135^{\mathrm{ab}} \pm 1$ & $135^{\mathrm{a}} \pm 1$ \\
\hline 4 & $112^{\mathrm{c}} \pm 1$ & $223^{c} \pm 1$ & $114^{\mathrm{b}} \pm 1$ & $224^{a} \pm 1$ & $132^{\mathrm{c}} \pm 1$ & $133^{b c} \pm 1$ & $134^{\mathrm{b}} \pm 1$ & $135^{\mathrm{a}} \pm 1$ \\
\hline 5 & $110^{d} \pm 1$ & $221^{d} \pm 1$ & $108^{\mathrm{d}} \pm 1$ & $222^{\mathrm{a}} \pm 1$ & $130^{d} \pm 1$ & $132^{c} \pm 1$ & $134^{b} \pm 1$ & $135^{\mathrm{a}} \pm 1$ \\
\hline
\end{tabular}


Egyptian J. of Nutrition Vol. XXXVI No. 1 (2021)

Count.Table2.

\begin{tabular}{|c|c|c|c|c|c|c|c|c|c|c|c|}
\hline \multicolumn{4}{|c|}{ Heat seal strength $(\mathrm{gm} / \mathrm{cm})$} & \multicolumn{4}{|c|}{$\begin{array}{l}\text { Water vapor permeability } \\
g_{\mathrm{H} 2 \mathrm{O} / \mathrm{m}^{2} . \mathrm{d}}\end{array}$} & \multicolumn{4}{|c|}{$\begin{array}{l}\text { Oxygen transmission rate } \\
\qquad \mathrm{Cm}^{3} \mathrm{O}_{2} / \mathrm{m}^{2} . \mathrm{d}\end{array}$} \\
\hline 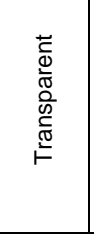 & $\begin{array}{l}\frac{0}{0} \\
\frac{N}{\pi} \\
\frac{\pi}{0} \\
\sum\end{array}$ & 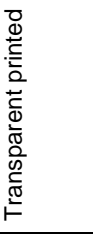 & 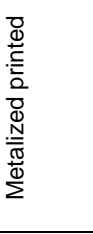 & 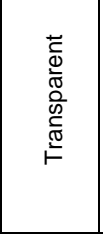 & 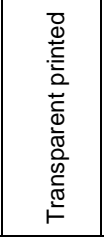 & $\begin{array}{l}\bar{D} \\
\frac{N}{\bar{N}} \\
\frac{\pi}{0} \\
\sum\end{array}$ & 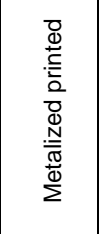 & 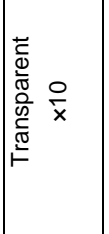 & 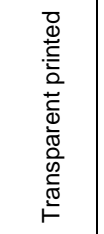 & $\begin{array}{l}\bar{D} \\
\frac{N}{\bar{N}} \\
\frac{\pi}{0} \\
\sum\end{array}$ & 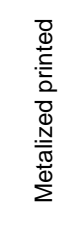 \\
\hline $182^{\mathrm{b}} \pm 1$ & $172^{b} \pm 1$ & $118^{\mathrm{c}} \pm 1$ & $118^{\mathrm{c}} \pm 1$ & $8.8^{\mathrm{a}} \pm 0.1$ & $4.5^{\mathrm{b}} \pm 0.1$ & $0.8^{\mathrm{a}} \pm 0.1$ & $0.2^{\mathrm{a}} \pm 0$ & $187^{a b} \pm 1$ & $480^{\circ} \pm 1$ & $145^{\mathrm{b}} \pm 1$ & $50^{a} \pm 1$ \\
\hline $180^{c} \pm 1$ & $170^{c} \pm 1$ & $110^{e} \pm 1$ & $126^{a} \pm 1$ & $8.2^{b} \pm 0.1$ & $4.8^{a} \pm 0.1$ & $\begin{array}{c}0.85^{\mathrm{a}} \pm 0 \\
01\end{array}$ & $0.2^{\mathrm{a}} \pm 0$ & $186^{b c} \pm 1$ & $450^{d} \pm 1$ & $150^{\mathrm{a}} \pm 1$ & $50^{a} \pm 1$ \\
\hline $178^{\mathrm{d}} \pm 1$ & $168^{\mathrm{d}} \pm 1$ & $120^{\mathrm{b}} \pm 1$ & $120^{\mathrm{b}} \pm 1$ & $7.8^{\mathrm{c}} \pm 0$ & $4.2^{\mathrm{c}} \pm 0$ & $0.85^{\mathrm{a}} \pm 0$ & $0.2^{\mathrm{a}} \pm 0$ & $186^{\mathrm{bc}} \pm 1$ & $490^{b} \pm 1$ & $145^{\mathrm{b}} \pm 1$ & $45^{b} \pm 1$ \\
\hline $182^{b} \pm 1$ & $172^{b} \pm 1$ & $115^{\mathrm{d}} \pm 1$ & $118^{\mathrm{c}} \pm 1$ & $7.8^{\mathrm{c}} \pm 0$ & $4.5^{\mathrm{b}} \pm 0$ & $0.86^{a} \pm 0$ & $0.16^{\mathrm{b}} \pm 0$ & $185^{\circ} \pm 1$ & $500^{a} \pm 1$ & $140^{c} \pm 1$ & $45^{b} \pm 1$ \\
\hline $185^{a} \pm 1$ & $175^{\mathrm{a}} \pm 1$ & $125^{\mathrm{a}} \pm 1$ & $118^{\mathrm{c}} \pm 1$ & $7.8^{\mathrm{c}} \pm 0$ & $4.9^{\mathrm{a}} \pm 0$ & $0.87^{a} \pm 0$ & $0.16^{\mathrm{b}} \pm 0$ & $188^{\mathrm{a}} \pm 1$ & $480^{\circ} \pm 1$ & $140^{\mathrm{c}} \pm 1$ & $45^{\mathrm{b}} \pm 1$ \\
\hline
\end{tabular}

Means followed by different small letters in the same row (effect of time) are significantly different by Duncan's multiple test $(\mathrm{P}<0.05)$ 
Nehad Mohamed Ibrahim, Yehia Abd El-Razik Heikal, Mamdouh Helmi El-Kalyoubi and Khaled Sayed Nagy

Table3. Tracing oxygen concentration in transparent and metalized bags of potato chips during storage

\begin{tabular}{|c|c|c|c|c|c|c|c|c|c|c|}
\hline \multirow{3}{*}{$\begin{array}{l}\text { Storage } \\
\text { condition }\end{array}$} & \multirow{3}{*}{$\begin{array}{c}\text { Type of } \\
\text { gas }\end{array}$} & \multicolumn{9}{|c|}{ Transparent bags } \\
\hline & & \multicolumn{9}{|c|}{ Storage weeks } \\
\hline & & 0 & 2 & 4 & 6 & 8 & 10 & 12 & 14 & 16 \\
\hline \multirow[t]{3}{*}{ winter (W) } & $\mathrm{N}_{2}$ & $98^{a} \pm 0$ & $96^{b} \pm 1$ & $94^{c} \pm 1$ & $91^{d} \pm 1$ & $87^{e} \pm 1$ & $85^{\dagger} \pm 1$ & $81^{9} \pm 1$ & $80^{g h} \pm 1$ & $79^{h} \pm 1$ \\
\hline & $\mathrm{O}_{2}$ & $2^{\mathrm{h}} \pm 0$ & $4^{9} \pm 1$ & $6^{f} \pm 1$ & $9^{e} \pm 1$ & $13^{d} \pm 1$ & $15^{c} \pm 1$ & $18^{b} \pm 1$ & $19^{b} \pm 1$ & $21^{a} \pm 1$ \\
\hline & $\mathrm{CO}_{2}$ & $0^{b} \pm 0$ & $0^{b} \pm 0$ & $0^{b} \pm 0$ & $0^{b} \pm 0$ & $0^{b} \pm 0$ & $0^{b} \pm 0$ & $0.1^{a} \pm 0$ & $0.1^{a} \pm 0$ & $0.1^{a} \pm 0$ \\
\hline \multirow[t]{3}{*}{ summer (S) } & $\mathrm{N}_{2}$ & $98^{\mathrm{a}} \pm 0$ & $94^{b} \pm 1$ & $91^{c} \pm 1$ & $84^{\mathrm{d}} \pm 1$ & $80^{e} \pm 1$ & $79^{e f} \pm 1$ & $78^{\dagger} \pm 1$ & $78^{\dagger} \pm 1$ & $78^{\dagger} \pm 1$ \\
\hline & $\mathrm{O}_{2}$ & $2^{\dagger} \pm 0$ & $6^{e} \pm 1$ & $9^{d} \pm 1$ & $16^{c} \pm 1$ & $19^{b} \pm 1$ & $20^{a b} \pm 1$ & $21^{a} \pm 1$ & $21^{a} \pm 1$ & $21^{a} \pm 1$ \\
\hline & $\mathrm{CO}_{2}$ & $0^{b} \pm 0$ & $0^{b} \pm 0$ & $0^{\mathrm{b}} \pm 0$ & $0^{b} \pm 0$ & $0.1^{\mathrm{a}} \pm 0$ & $0.1^{\mathrm{a}} \pm 0$ & $0.1^{\mathrm{a}} \pm 0$ & $0.1^{\mathrm{a}} \pm 0$ & $0.1^{a} \pm 0$ \\
\hline \multirow{3}{*}{$\begin{array}{c}\text { outside } \\
\text { condition }(\mathrm{O})\end{array}$} & $\mathrm{N}_{2}$ & $98^{\mathrm{a}} \pm 0$ & $90^{b} \pm 1$ & $85^{c} \pm 1$ & $80^{d} \pm 1$ & $79^{\text {de }} \pm 1$ & $78^{e} \pm 1$ & $78^{e} \pm 1$ & $78^{e} \pm 1$ & $78^{e} \pm 1$ \\
\hline & $\mathrm{O}_{2}$ & $2^{e} \pm 0$ & $10^{d} \pm 1$ & $15^{c} \pm 1$ & $19^{b} \pm 1$ & $20^{\mathrm{ab}} \pm 1$ & $21^{a} \pm 1$ & $21^{a} \pm 1$ & $21^{a} \pm 1$ & $21^{a} \pm 1$ \\
\hline & $\mathrm{Co}_{2}$ & $0^{b} \pm 0$ & $0^{\mathrm{b}} \pm 0$ & $0^{\mathrm{b}} \pm 0$ & $0.1^{\mathrm{a}} \pm 0$ & $0.1^{\mathrm{a}} \pm 0$ & $0.1^{\mathrm{a}} \pm 0$ & $0.1^{a} \pm 0$ & $0.1^{\mathrm{a}} \pm 0$ & $0.1^{\mathrm{a}} \pm 0$ \\
\hline
\end{tabular}


Egyptian J. of Nutrition Vol. XXXVI No. 1 (2021)

\section{Count.Table3.}

\begin{tabular}{|c|c|c|c|c|c|c|c|c|c|c|c|c|c|}
\hline \multirow{2}{*}{ Type of gas } & \multicolumn{13}{|c|}{$\begin{array}{l}\text { Metalized bags } \\
\text { Storage weeks }\end{array}$} \\
\hline & 0 & 2 & 4 & 6 & 8 & 10 & 12 & 14 & 16 & 18 & 20 & 22 & 24 \\
\hline $\mathrm{N}_{2}$ & $98^{\mathrm{a}} \pm 0$ & $97^{a b} \pm 1$ & $96^{\mathrm{bc}} \pm 1$ & $95^{\mathrm{cd}} \pm 1$ & $94^{d} \pm 1$ & $91^{\mathrm{e}} \pm 1$ & $90^{\mathrm{fg}} \pm 1$ & $89^{g h} \pm 1$ & $88^{\mathrm{h}} \pm 1$ & $88^{\mathrm{h}} \pm 1$ & $83^{i} \pm 1$ & $81^{\mathrm{i}} \pm 1$ & $80^{j} \pm 1$ \\
\hline $\mathrm{O}_{2}$ & $2^{j} \pm 0$ & $3^{i \mathrm{ij}} \pm 1$ & $4^{\mathrm{hi}_{1}} \pm 1$ & $5^{g h} \pm 1$ & $6^{9} \pm 1$ & $8^{f} \pm 1$ & $9^{e f} \pm 1$ & $10^{d e} \pm 1$ & $11^{d} \pm 1$ & $11^{d} \pm 1$ & $16^{c} \pm 1$ & $18^{\mathrm{b}} \pm 1$ & $20^{a} \pm 1$ \\
\hline $\mathrm{Co}_{2}$ & $0^{\mathrm{b}} \pm 0$ & $0^{\mathrm{b}} \pm 0$ & $0^{\mathrm{b}} \pm 0$ & $0^{\mathrm{b}} \pm 0$ & $0^{\mathrm{b}} \pm 0$ & $0.1^{\mathrm{a}} \pm 1$ & $0.1^{a} \pm 1$ & $0.1^{\mathrm{a}} \pm 1$ & $0.1^{a} \pm 1$ & $0.1^{a} \pm 1$ & $0.1^{\mathrm{a}} \pm 1$ & $0.1^{\mathrm{a}} \pm 1$ & $0.1^{\mathrm{a}} \pm 1$ \\
\hline $\mathrm{N}_{2}$ & $98^{a} \pm 0$ & $95^{b} \pm 1$ & $95^{b} \pm 1$ & $94^{b c} \pm 1$ & $93^{c} \pm 1$ & $91^{d} \pm 1$ & $90^{d e} \pm 1$ & $89^{e} \pm 1$ & $87^{f} \pm 1$ & $87^{f} \pm 1$ & $80^{9} \pm 1$ & $80^{9} \pm 1$ & $78^{h} \pm 1$ \\
\hline $\mathrm{O}_{2}$ & $2^{i} \pm 0$ & $5^{h} \pm 1$ & $5^{h} \pm 1$ & $6^{g h} \pm 1$ & $7^{\mathrm{fg}} \pm 1$ & $8^{\mathrm{ef}} \pm 1$ & $9^{d e} \pm 1$ & $10^{d} \pm 1$ & $12^{\mathrm{c}} \pm 1$ & $12^{\mathrm{c}} \pm 1$ & $19^{b} \pm 1$ & $19^{b} \pm 1$ & $21^{a} \pm 1$ \\
\hline $\mathrm{CO}_{2}$ & $0^{\mathrm{b}} \pm 0$ & $0^{\mathrm{b}} \pm 0$ & $0^{\mathrm{b}} \pm 0$ & $0^{\mathrm{b}} \pm 0$ & $0^{\mathrm{b}} \pm 0$ & $0.1^{a} \pm 1$ & $0.1^{a} \pm 1$ & $0.1^{a} \pm 1$ & $0.1^{a} \pm 1$ & $0.1^{a} \pm 1$ & $0.1^{a} \pm 1$ & $0.1^{\mathrm{a}} \pm 1$ & $0.1^{a} \pm 1$ \\
\hline $\mathrm{N}_{2}$ & $98^{\mathrm{a}} \pm 0$ & $95^{\mathrm{b}} \pm 1$ & $94^{\mathrm{bc}} \pm 1$ & $93^{c d} \pm 1$ & $92^{d} \pm 1$ & $90^{\mathrm{e}} \pm 1$ & $88^{f} \pm 1$ & $87^{\dagger} \pm 1$ & $85^{9} \pm 1$ & $85^{9} \pm 1$ & $80^{h} \pm 1$ & $79^{h_{i}} \pm 1$ & $78^{i} \pm 1$ \\
\hline $\mathrm{O}_{2}$ & $2^{i} \pm 0$ & $5^{h} \pm 1$ & $6^{g h} \pm 1$ & $7^{\mathrm{fg}} \pm 1$ & $8^{\mathrm{ef}} \pm 1$ & $9^{e} \pm 1$ & $11^{d} \pm 1$ & $12^{\mathrm{d}} \pm 1$ & $14^{\mathrm{c}} \pm 1$ & $14^{\mathrm{c}} \pm 1$ & $19^{b} \pm 1$ & $20^{a b} \pm 1$ & $21^{a} \pm 1$ \\
\hline $\mathrm{Co}_{2}$ & $0^{b} \pm 0$ & $0^{b} \pm 0$ & $0^{\mathrm{b}} \pm 0$ & $0^{\mathrm{b}} \pm 0$ & $0^{\mathrm{b}} \pm 0$ & $0.1^{\mathrm{a}} \pm 1$ & $0.1^{\mathrm{a}} \pm 1$ & $0.1^{\mathrm{a}} \pm 1$ & $0.1^{\mathrm{a}} \pm 1$ & $0.1^{\mathrm{a}} \pm 1$ & $0.1^{\mathrm{a}} \pm 1$ & $0.1^{a} \pm 1$ & $0.1^{\mathrm{a}} \pm 1$ \\
\hline
\end{tabular}

Means followed by different small letters in the same row (effect of time) are significantly different by Duncan's multiple test $(\mathrm{P}<0.05)$ 
Nehad Mohamed Ibrahim, Yehia Abd El-Razik Heikal, Mamdouh Helmi El-Kalyoubi and Khaled Sayed Nagy

Table4. Change in moisture content for potato chips packed in Transparent and Metallized BOPP bags under nitrogen atmosphere

\begin{tabular}{|c|c|c|c|c|c|c|c|c|c|c|}
\hline \multirow{4}{*}{$\begin{array}{l}\text { Type of gas } \\
\text { atmosphe re }\end{array}$} & \multirow{4}{*}{$\begin{array}{l}\text { Storage } \\
\text { condition }\end{array}$} & \multicolumn{9}{|c|}{ Moisture content of chips packed in (\% d.b) } \\
\hline & & \multicolumn{9}{|c|}{ Transparent BOPP bags } \\
\hline & & \multicolumn{9}{|c|}{ Weeks of storage } \\
\hline & & 0 & 4 & 8 & 12 & 16 & 20 & 24 & 28 & 32 \\
\hline \multirow{3}{*}{$\mathrm{N}_{2}$} & $\begin{array}{l}\text { Winter } \\
\text { (W) }\end{array}$ & $1^{i} \pm 0$ & $1.4^{\mathrm{h}} \pm 0.1$ & $1.8^{9} \pm 0.06$ & $2.2^{f} \pm 0.06$ & $2.9^{e} \pm 0.1$ & $3.4^{\mathrm{d}} \pm 0.06$ & $4.1^{c} \pm 0.06$ & $4.7^{\mathrm{b}} \pm 0.06$ & $5^{\mathrm{a}} \pm 0$ \\
\hline & $\begin{array}{l}\text { Summer } \\
\text { (S) }\end{array}$ & $1^{i} \pm^{0}$ & $1.3^{\mathrm{h}} \pm 0.1$ & $1.5^{9} \pm 0.1$ & $1.9^{f} \pm 0.1$ & $2.4^{\mathrm{e}} \pm 0.1$ & $2.8^{\mathrm{d}} \pm 0.1$ & $3.2^{\mathrm{c}} \pm 0.1$ & $3.8^{\mathrm{b}} \pm 0.1$ & $4^{\mathrm{a}} \pm 0$ \\
\hline & $\begin{array}{c}\text { Outdoor } \\
\text { (O) }\end{array}$ & $1^{i} \pm 0$ & $1.4^{\mathrm{h}} \pm 0.1$ & $1.6^{g} \pm 0.1$ & $2.1^{\dagger} \pm 0.1$ & $2.7^{e} \pm 0.1$ & $3.1^{d} \pm 0.15$ & $4^{\mathrm{b}} \pm 0$ & $3.5^{\mathrm{c}} \pm 0.1$ & $5^{a} \pm 0$ \\
\hline
\end{tabular}

Count.Table 4.

\begin{tabular}{|c|c|c|c|c|c|c|c|c|c|c|c|c|}
\hline \multicolumn{13}{|c|}{ Metallized BOPP bags } \\
\hline \multicolumn{13}{|c|}{ Weeks of storage } \\
\hline 0 & 4 & 8 & 12 & 16 & 20 & 24 & 28 & 32 & 36 & 40 & 44 & 48 \\
\hline $1.1^{\mathrm{h}} \pm 0$ & $1.2^{9} \pm 0.06$ & $1.3^{\mathrm{fg}} \pm 0.1$ & $1.5^{\mathrm{e}} \pm 0.06$ & $1.4^{f} \pm 0.1$ & $1.4^{\dagger} \pm 0.1$ & $1.5^{\mathrm{e}} \pm 0.06$ & $1.5^{\mathrm{e}} \pm 0.06$ & $1.8^{\mathrm{d}} \pm 0.06$ & $1.9^{\text {cd }} \pm 0.06$ & $2^{c} \pm 0$ & $2.3^{\mathrm{b}} \pm 0.1$ & $4^{a} \pm 0$ \\
\hline $1.2^{\mathrm{h}} \pm 0$ & $1.3^{g^{h}} \pm 0.1$ & $1.4^{\mathrm{fg}} \pm 0.1$ & $1.6^{\mathrm{de}} \pm 0.1$ & $1.5^{\text {ef }} \pm 0.1$ & $1.5^{\mathrm{ef}} \pm 0.1$ & $1.6^{\mathrm{de}^{2}} \pm 0.1$ & $1.6^{\mathrm{de}} \pm 0.1$ & $1.7^{\mathrm{d}} \pm 0.1$ & $1.9^{\mathrm{c}} \pm 0.1$ & $2^{\mathrm{c}} \pm 0$ & $2.3^{\mathrm{b}} \pm 0.1$ & $4^{\mathrm{a}} \pm 0$ \\
\hline $1.1^{\mathrm{h}} \pm 0$ & $1.2^{9} \pm 0.1$ & $1.2^{9} \pm 0.1$ & $1.4^{f} \pm 0.1$ & $1.4^{f} \pm 0.1$ & $1.4^{f} \pm 0.1$ & $1.5^{\mathrm{e}} \pm 0.1$ & $1.5^{e} \pm 0.1$ & $1.8^{\mathrm{d}} \pm 0.1$ & $1.8^{\mathrm{d}} \pm 0.1$ & $2^{\mathrm{c}} \pm 0.1$ & $2.2^{\mathrm{b}} \pm 0.1$ & $5^{\mathrm{a}} \pm 0$ \\
\hline
\end{tabular}

Means followed by different small letters in the same row (effect of time) are significantly different by Duncan's multiple test $(P<0.05)$ 
Egyptian J. of Nutrition Vol. XXXVI No. 1 (2021)

Table 5. Change in peroxide value for potato chips packed intransparent and metalized BOPP bags under nitrogen or air atmosphere

\begin{tabular}{|c|c|c|c|c|c|c|}
\hline \multirow{4}{*}{$\begin{array}{l}\text { Type of gas } \\
\text { atmosphere }\end{array}$} & \multirow[t]{4}{*}{ Storage condition } & \multicolumn{5}{|c|}{ Peroxide value for chipspackedin (mg Eq / kgoil) } \\
\hline & & \multicolumn{5}{|c|}{ Transparent bags } \\
\hline & & \multicolumn{5}{|c|}{ Weeks of storage } \\
\hline & & 0 & 4 & 8 & 12 & 16 \\
\hline \multirow[t]{3}{*}{$\mathrm{N}_{2}$} & $\begin{array}{l}\text { Winter } \\
\text { (W) }\end{array}$ & $0^{d} \pm 0$ & $0^{d} \pm 0$ & $0.1^{c} \pm 0$ & $0.14^{b} \pm 0$ & $0.16^{\mathrm{a}} \pm 0$ \\
\hline & $\begin{array}{l}\text { Summer } \\
\text { (S) }\end{array}$ & $0^{d} \pm 0$ & $0^{\mathrm{d}} \pm 0$ & $0.12^{\mathrm{c}} \pm 0$ & $0.15^{b} \pm 0$ & $0.18^{\mathrm{a}} \pm 0$ \\
\hline & $\begin{array}{l}\text { Outdoor } \\
\text { (O) }\end{array}$ & $0^{d} \pm 0$ & $0^{d} \pm 0$ & $0.14^{c} \pm 0$ & $0.18^{\mathrm{b}} \pm 0$ & $0.2^{\mathrm{a}} \pm 0$ \\
\hline \multirow[t]{3}{*}{ Air } & $\begin{array}{l}\text { Winter } \\
\text { (W) }\end{array}$ & $0^{e} \pm 0$ & $0.12^{\mathrm{d}} \pm 0$ & $0.24^{\mathrm{c}} \pm 0$ & $0.36^{\mathrm{b}} \pm 0$ & $0.58^{\mathrm{a}} \pm 0$ \\
\hline & $\begin{array}{l}\text { Summer } \\
\text { (S) }\end{array}$ & $0^{\mathrm{e}} \pm 0$ & $0.14^{d} \pm 0$ & $0.25^{c} \pm 0$ & $0.4^{b} \pm 0$ & $0.51^{a} \pm 0$ \\
\hline & $\begin{array}{l}\text { Outdoor } \\
\text { (O) }\end{array}$ & $0^{e} \pm 0$ & $0.18^{\mathrm{d}} \pm 0$ & $0.3^{c} \pm 0$ & $0.53^{b} \pm 0$ & $0.65^{\mathrm{a}} \pm 0$ \\
\hline
\end{tabular}


Nehad Mohamed Ibrahim, Yehia Abd El-Razik Heikal, Mamdouh Helmi El-Kalyoubi and Khaled Sayed Nagy

\section{Count.Table5.}

\begin{tabular}{|c|c|c|c|c|c|c|c|c|c|}
\hline & & & & \multicolumn{6}{|c|}{ Metallized bags } \\
\hline & & & & \multicolumn{6}{|c|}{ Weeks of storage } \\
\hline 0 & 4 & 8 & 12 & 16 & 20 & 24 & 28 & 32 & 36 \\
\hline $0^{g} \pm 0$ & $0^{g} \pm 0$ & $0^{g} \pm 0$ & $0^{9} \pm 0$ & $0.1^{f} \pm 0$ & $0.11^{e} \pm 0$ & $0.12^{\mathrm{d}} \pm 0$ & $0.14^{c} \pm 0$ & $0.16^{b} \pm 0$ & $0.18^{a} \pm 0$ \\
\hline $0^{9} \pm 0$ & $0^{g} \pm 0$ & $0^{9} \pm 0$ & $0^{g} \pm 0$ & $0.11^{f} \pm 0$ & $0.13^{e} \pm 0$ & $0.14^{d} \pm 0$ & $0.15^{c} \pm 0$ & $0.18^{\mathrm{b}} \pm 0$ & $0.21^{a} \pm 0$ \\
\hline $0^{i} \pm 0$ & $0^{i} \pm 0$ & $0.14^{\mathrm{h}} \pm 0$ & $0.16^{9} \pm 0$ & $0.18^{f} \pm 0$ & $0.2^{\mathrm{e}} \pm 0$ & $0.24^{d} \pm 0$ & $0.26^{c} \pm 0$ & $0.28^{\mathrm{b}} \pm 0$ & $0.31^{a} \pm 0$ \\
\hline $0^{i} \pm 0$ & $0^{i} \pm 0$ & $0.15^{\mathrm{h}} \pm 0$ & $0.18^{g} \pm 0$ & $0.21^{\mathrm{f}} \pm 0$ & $0.27^{e} \pm 0$ & $0.3^{\mathrm{d}} \pm 0$ & $0.36^{c} \pm 0$ & $0.48^{\mathrm{b}} \pm 0$ & $0.6^{\mathrm{a}} \pm 0$ \\
\hline $0^{\mathrm{h}} \pm 0$ & $0^{h} \pm 0$ & $0.26^{g} \pm 0$ & $0.28^{f} \pm 0$ & $0.28^{f} \pm 0$ & $0.32^{\mathrm{e}} \pm 0$ & $0.35^{d} \pm 0$ & $0.4^{c} \pm 0$ & $0.51^{\mathrm{b}} \pm 0$ & $0.68^{a} \pm 0$ \\
\hline $0^{i} \pm 0$ & $0^{i} \pm 0$ & $0.14^{h} \pm 0$ & $0.16^{9} \pm 0$ & $0.34^{\dagger} \pm 0$ & $0.41^{e} \pm 0$ & $0.44^{d} \pm 0$ & $0.53^{c} \pm 0$ & $0.65^{\mathrm{b}} \pm 0$ & $0.88^{a} \pm 0$ \\
\hline
\end{tabular}

Means followed by different small letters in the same row (effect of time) are significantly different by Duncan's multiple test $(\mathrm{P}<0.05)$ 
Egyptian J. of Nutrition Vol. XXXVI No. 1 (2021)

Table (6) Microbial quality of potato chips during storage

\begin{tabular}{|c|c|c|c|c|c|c|c|c|c|c|c|c|c|c|c|c|c|}
\hline \multirow{4}{*}{$\begin{array}{l}\text { Type of gas } \\
\text { atmosphere }\end{array}$} & \multirow{4}{*}{$\begin{array}{l}\text { Storage } \\
\text { condition }\end{array}$} & \multicolumn{16}{|c|}{ Type of used BOPP bags } \\
\hline & & \multicolumn{6}{|c|}{ Transparent } & \multicolumn{10}{|c|}{ Metalized } \\
\hline & & \multicolumn{16}{|c|}{ Total bacteria count (CFU) } \\
\hline & & $\mathrm{N}$ & D & 4 & 8 & 12 & 16 & 0 & 4 & 8 & 12 & 16 & 20 & 24 & 28 & 32 & 36 \\
\hline \multirow{3}{*}{$\mathrm{N}_{2}$} & W & $\mathrm{N}$ & D & ND & ND & ND & 5 & ND & ND & ND & ND & ND & ND & ND & ND & 5 & 10 \\
\hline & $S$ & $\mathrm{~N}$ & D & ND & ND & ND & 5 & ND & ND & ND & ND & ND & ND & ND & ND & 8 & 15 \\
\hline & $\mathrm{O}$ & $\mathrm{N}$ & D & ND & ND & 8 & 10 & ND & ND & ND & ND & ND & ND & ND & 5 & 8 & 20 \\
\hline \multirow{3}{*}{ Air } & W & $\mathrm{N}$ & D & ND & ND & 5 & 10 & ND & ND & ND & ND & ND & ND & 5 & 8 & 10 & 15 \\
\hline & $S$ & $\mathrm{~N}$ & ID & ND & ND & 8 & 12 & ND & ND & ND & ND & ND & 5 & 8 & 10 & 15 & 15 \\
\hline & $\mathrm{O}$ & $\mathrm{N}$ & ID & ND & 5 & 10 & 15 & ND & ND & ND & ND & ND & 10 & 12 & 16 & 16 & 20 \\
\hline \multicolumn{18}{|c|}{ Yeast and mold(CFU) } \\
\hline \multirow{3}{*}{$\mathrm{N}_{2}$} & W & ND & ND & ND & ND & 5 & 5 & ND & ND & ND & ND & ND & ND & ND & ND & 5 & 8 \\
\hline & $S$ & ND & ND & ND & ND & 5 & 5 & ND & ND & ND & ND & ND & ND & ND & ND & 8 & 8 \\
\hline & 0 & ND & ND & ND & ND & 8 & 10 & ND & ND & ND & ND & ND & ND & ND & 5 & 8 & 10 \\
\hline \multirow{3}{*}{ Air } & W & ND & ND & ND & 5 & 8 & 10 & ND & ND & ND & ND & ND & ND & 5 & 8 & 10 & 12 \\
\hline & $S$ & ND & ND & ND & 5 & 10 & 12 & ND & ND & ND & ND & ND & ND & 5 & 5 & 15 & 15 \\
\hline & 0 & ND & ND & 5 & 5 & 8 & 15 & ND & ND & ND & ND & ND & 5 & 5 & 10 & 12 & 16 \\
\hline
\end{tabular}


Nehad Mohamed Ibrahim, Yehia Abd El-Razik Heikal, Mamdouh Helmi El-Kalyoubi and Khaled Sayed Nagy
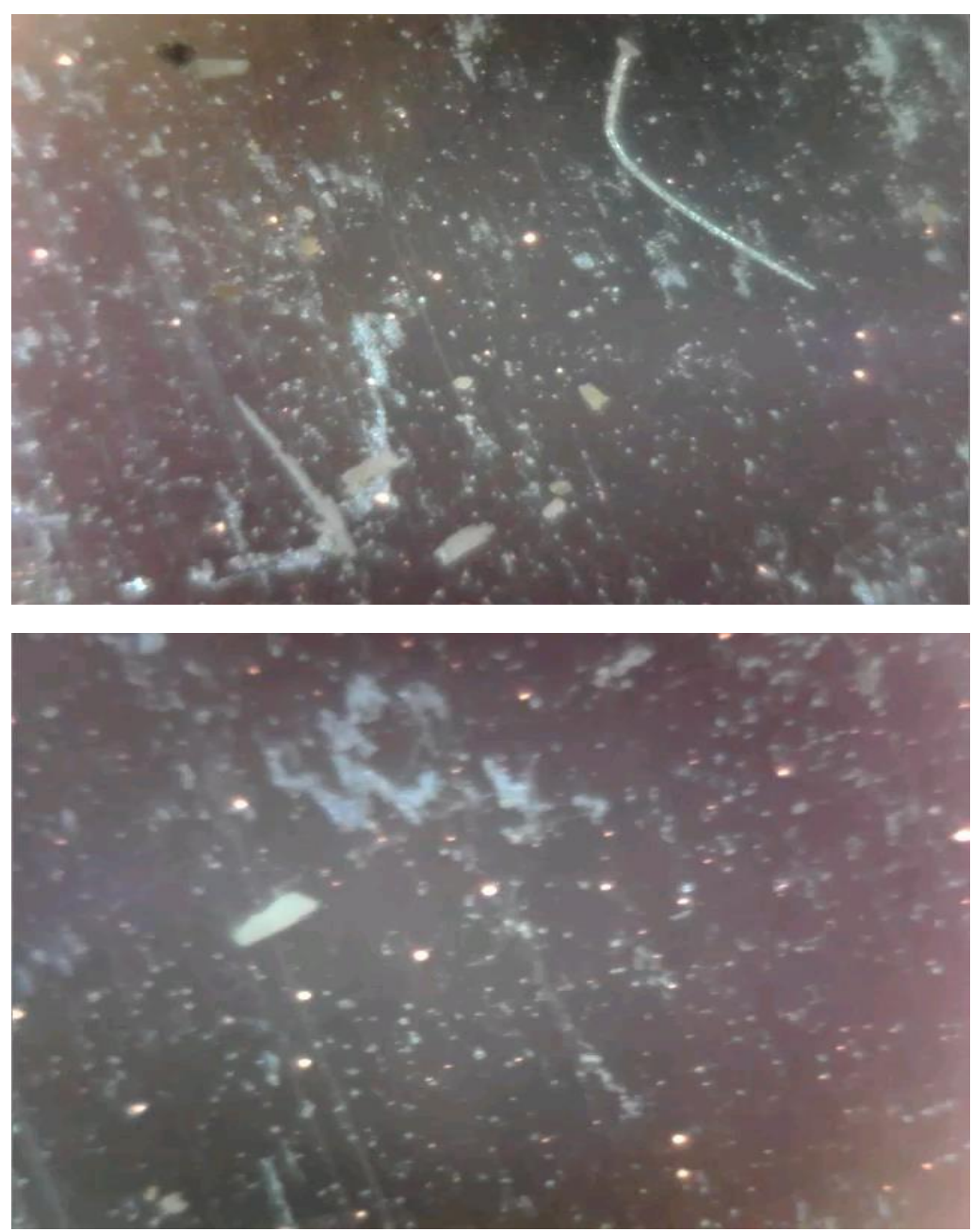

Fig (1) Optical microscope surface appearance of metalized BOPP film $(\times 500)$ 
Egyptian J. of Nutrition Vol. XXXVI No. 1 (2021)

\section{Reference}

Adjouman, YD; Nindjin, C; Tetchi, FA; Dalcq, AC; Amani, NG. and Sindic, M (2017)

Water Vapor Permeability of edible films based on improved cassava native starches. Journal of Food Processing and Technology, Vol. 8, issue 2. P $2-6$.

Agarwal, D.; Mui, L.; Aldridge, E.; Mottram, R.; McKinney, J. and Fisk, I. D. (2018)

The impact of nitrogen gas flushing on the stability of seasonings: volatile compounds and sensory perception of cheese \& onion seasoned potato crisps. Food \& function, 9(9) 4730-4741

Ahmed, T.; Sharmin, A.; Paul, A.; Dipu, M. R. and Islam, T. (2020)

Microbiological quality analysis of different types of popular dried food items. Food Research, 4(4), 12971302. 
Nehad Mohamed Ibrahim, Yehia Abd El-Razik Heikal, Mamdouh Helmi El-Kalyoubi and Khaled Sayed Nagy

Allahvaisi, S. (2012)

Polypropylene in the industry of food packaging (Chapter 1 , PP 3 - 22, Polypropylene, Faith Dogom, Ed.) ISBN: 978 953 - 51. On 36 - 4, in Tech. available from: www. Intechopen. Com / books / Polypropylene/ Polypropylene in - the - industry - of - food -Packaging.

AOAC (2000)

Official methods of analysis of AOAC International, (17th ed.), Gaithersburg, MD, USA: AOAC.

ASTM (1987)

American Society of Materials: Standard Test Method for Tensile Strength of Plastic materials, D882-83. Penselvania, USA.

ASTM (1987)

American Society of Materials: Standard Test Method for Water Vapor Transmission Rate (WVTR) of Plastic materials, D - 895. Penselvania, USA. 
Egyptian J. of Nutrition Vol. XXXVI No. 1 (2021)

ASTM (1987)

American Society of Materials: Standard Test Method for Seal Strength of Plastic materials, D882-83. Penselvania, USA.

Bradley, R. I. (2010)

Moisture and Total solids analysis.In: Nielsen, food analysis, pp. 85 - 104, Springer publishing, Bosto, MA (USA).

Du, K.; Huang, J.; Chen, J.; Li, Y.; Yang, C. and Xia, X. (2020) Mechanical Property and Structure of Polypropylene/Aluminum Alloy Hybrid Prepared via Ultrasound-Assisted Hot-Pressing Technology. Materials, 13(1) 236.

Dunno, K. (2014)

Effects of Transportation Hazards on Package Performance and Food Product Shelf Life. All Dissertations, 1432. https://ingerprints. Clemson. Edu/all - dissertations/1432 
Nehad Mohamed Ibrahim, Yehia Abd El-Razik Heikal, Mamdouh Helmi El-Kalyoubi and Khaled Sayed Nagy

ES 1629 (2017)

Egyptian Organization for Standard and quality: Fried Potato, ES: 1629/2017, Arab Republic of Egypt, ICS: 67.080.20.

Esmer, O.K.; Irkin,R.; Degirmencioglu, N. and Degirmencioglu, A. (2011)

The effects of modified atmosphere gas composition on microbiological criteria, color and oxidation values of minced beef meat. Meat science, 88(2) 221-226.

Farris, S.; Cozzolino, C. A.; Introzzi, L. and Piergiovanni, L. (2009)

Effects of different sealing conditions on the seal strength of polypropylene films coated with a bio-based thin layer. Packaging Technology and Science: An International Journal, 22(6), 359-369.

Gajdoš, J.; Galić, K.; Kurtanjek, Ž.; and Ciković, N. (2000) Gas permeability and DSC characteristics of polymers used in food packaging. Polymer Testing, 20(1) 49-57. 
Egyptian J. of Nutrition Vol. XXXVI No. 1 (2021)

Goekmen, S. (2004)

Effect of moisture content and popping method on popping characteristics of popcorn. Journal of Food Engineering 65(3) : $357-362$.

ISO. (2006)

International Organization for Standardization. Microbiology of Food and Animal Feeding Stuffs: Horizontal Method for the Enumeration of COLIFORMS - COLONY - COUNT TECHNIQUE ISO - 4832. 2006, Geneva, Switzerland.

ISO. (2010)

International Organization for Standardization. Plastic film and sheeting determination of gas transmission rate No.15105 - part 1, Bureau of Indian standards, New Delhi, Indian.

ISO. (2013)

International Organization for Standardization. Microbiology of Food and Animal Feeding Stuffs: Horizontal Method for the Enumeration of Yeasts and Moulds. ISO 21527 - 2, publisher :Interstandard (Russia). 
Nehad Mohamed Ibrahim, Yehia Abd El-Razik Heikal, Mamdouh Helmi El-Kalyoubi and Khaled Sayed Nagy

ISO. (2013)

International Organization for Standardization.

Microbiology of Food and Animal Feeding Stuffs:

Horizontal Method for the Enumeration of Colony count at $30^{\circ} \mathrm{C}$ by the pour plate technique. ISO $-48331-1$.

ISO. (2016)

International Organization for Standardization. ISO 2286 Specific methods for determining the total mass per unit area of the coating, Geneve, Switzerland.

IUFOST. (2020)

(International Uninon of Food Scienc and Technology): (2020) Module III shelf life Testing of foods, Chapter 6 : Savory snack foods (potato chips), ready to eat cereals and snacks. lufost. Org, Ontario, Canada.

Kaur, A.; Singh, N. and Ezekiel, R. (2008)

Quality parameters of potato chips from different potato cultivars: Effect of prior storage and frying temperatures. International journal of food properties,11(4)791-803. 
Egyptian J. of Nutrition Vol. XXXVI No. 1 (2021)

Khalifa, I. (2016)

Effect of Printing and Lamination techniques on barrier properties for polypropelene film. EC Nutrition, Vol.5 (2) : 1089 - 1099.

Lazić, V.; Budinski-Simendić, J.; Gvozdenović, J. and Simendić, B. (2010)

Barrier properties of coated and laminated polyolefin films for food packaging. Acta Physica Polonica A, 117(5), 855-858.

Lee, J. H. and Pangloli, P. (2013)

Volatile compounds and storage stability of potato chips fried in mid-oleic sunflower oil. International Journal of Food Properties, 16(3) 563-573.

MarDruk, (2009)

BOPP metallized film specifications. MarDruck opako wania company, Poland.

Marra, J. V. (1988)

Metallized OPP film, surface characteristics and physical properties. Journal of Plastic Film \& Sheeting, 4(1) 2734. 
Nehad Mohamed Ibrahim, Yehia Abd El-Razik Heikal, Mamdouh Helmi El-Kalyoubi and Khaled Sayed Nagy

Market Research (2020)

The future of market research. 2020 and beyond. Question pro Survey software: $800-531$ - 228: qustion pro.com / blog / future - of - market - research/

Mueller, K.; Schoenweitz, C. and Langowski, H. C. (2012)

Thin laminate films for barrier packaging applicationinfluence of down gauging and substrate surface properties on the permeation properties. Packaging Technology and Science, 25(3), 137-148.

Pangloli, P.; Melton, S. L.; Collins, J. L.; Penfield, M. P. and Saxton, A. M. (2002)

Flavor and storage stability of potato chips fried in cottonseed and sunflower oils and palm olein/sunflower oil blends. Journal of food science, 67(1) 97-103.

Petukhov, I.; Malcolmson, L. J.; Przybylski, R. and Armstrong, L. (1999)

Storage stability of potato chips fried in genetically modified canola oils. Journal of the American Oil Chemists' Society, 76(8) 889-896. 
Egyptian J. of Nutrition Vol. XXXVI No. 1 (2021)

Rade, D.; Mokrovcak, Z and Strucelj, D. (1997)

Deep fat frying of fresh fried potatoes in palm oil and vegetable oil. Food Technology and Biotechnology 35 (2), pp.119- 124.

Raheem, D. (2013)

Application of plastics and paper as food packaging materials-An overview. Emirates Journal of Food and Agriculture, 177-188.

Rahmatollahpur, S., Tohidi, T., \& Jamshidi-Ghaleh, K. (2010) Investigation of aluminium thin layer microstructure on BOPP polymer substrate. Journal of materials science, 45(7), 1937-1941.

Robards, K.; Amanda F. Kerr; Emillos Pastalides and John Karth (1988)

Headspace gas analysis as a measure of rancidity in corn chips. JAOCS, Vol. 65, no.10 pp: 1621 - 1626.

Saranya, K. K. and Barathi, B. (2012)

Quality of potato chips fried in different oils. Indian $\mathrm{J}$ Appl Res, 2, 90-92. 
Nehad Mohamed Ibrahim, Yehia Abd El-Razik Heikal, Mamdouh Helmi El-Kalyoubi and Khaled Sayed Nagy

Silva, A.; De Quirós, A. R. B.; López-Hernández, J. and Paseiro-Losada, P. (2004)

Determination of hexanal as indicator of the lipidic oxidation state in potato crisps using gas chromatography and high-performance liquid chromatography. Journal of Chromatography A, 1046(12) $75-81$.

Simseker, O.; Kurt, B. and Arman, E. (2012)

Effects of different solvents to printability in gravure printing. Asian Journal of Chemistry, 24(11) 5253-5256.

SPSS (2006)

Statistical Package for the social sciences(SPSS) Version 15.0 Chicago, IL: USA: SPSS.

Statistic year book of Egypt. (2017)

www. Capmas. gov. eg / pages / Statistic pages. aspx?

Page $-i d=5034$ 
Egyptian J. of Nutrition Vol. XXXVI No. 1 (2021)

Teixeira, C. E. F.; Rebechi, I. D. A. and Fontaneli, R. S. (2017)

Digital micrometer used in thickness measurement of plastic film compared to standardized instrument. Materials Sciences and Appications (8) : 577 - 583.

Valentas, Kj.; E. Rotstein and RP. Singh (1997)

Handbook of Food engineering practice, P 355 - 359 CRC, New York

Vassiliadi, E. and Tarantili, P. A. (2007)

Characterization of metallized biaxially oriented polypropylene film. Journal of applied polymer science, 105(4) 1713-1722.

Vinothini, K.; Sasikala, S. and Anjana Bora, S. A. M. (2015) Storage Studies of Indian Fried Snack Food Incorporated with Ivy Gourd. Ijltemas, volume IV, issue IV, PP 32 - 37.

Wade, W. N.; Vasdinnyei, R.; Deak, T.; and Beuchat, L. R. (2003) Proteolytic yeasts isolated from raw, ripe tomatoes and metabiotic association of Geotrichum candidum with Salmonella. International journal of food microbiology, 86(1-2), 101-111. 
Nehad Mohamed Ibrahim, Yehia Abd El-Razik Heikal, Mamdouh Helmi El-Kalyoubi and Khaled Sayed Nagy

\author{
تقييم جودة رقائق البطاطس المعبأة في أكياس من البولي بروبيلين \\ نهاد محمد ابراهيم , يحي عبد الرازق هيكل , ممدوح حلمي القليوبي , خالد سيد ناجي

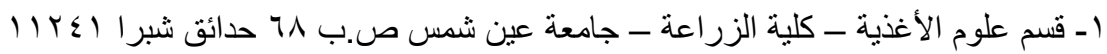

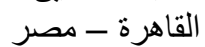

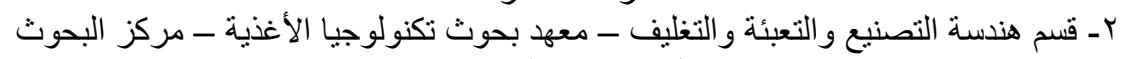

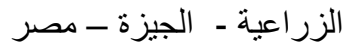 \\ الملخص العربي
}

يهدف البحث الي تقييم جودة رقائق البطاطس المعبأة في أكياس من البولي بروبيلين ثنائية

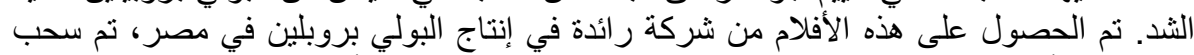

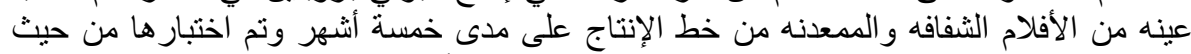

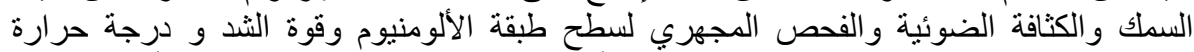

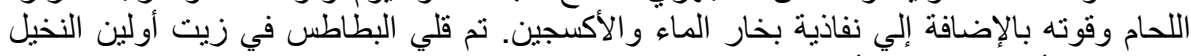

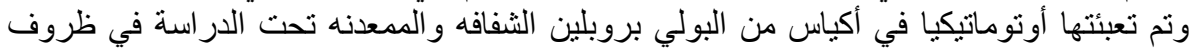

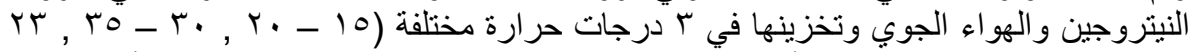
-

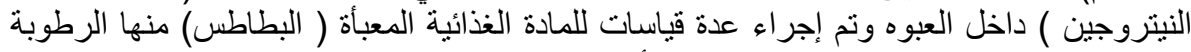

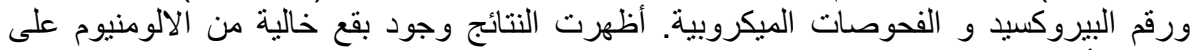

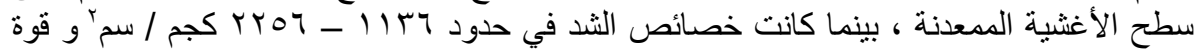

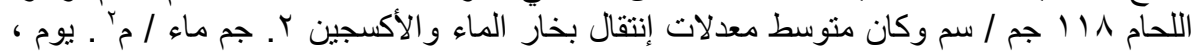

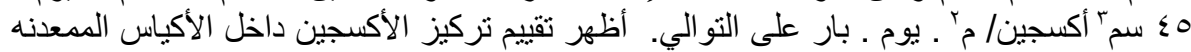

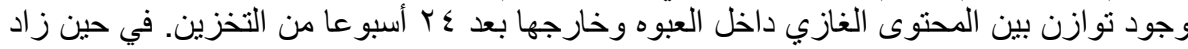

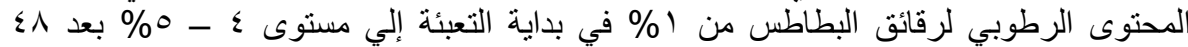

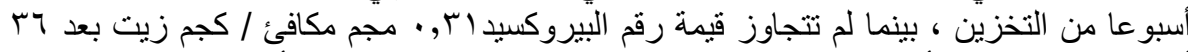

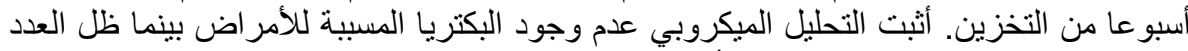

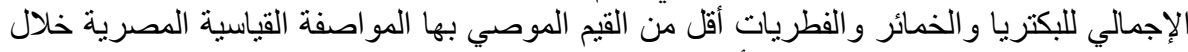

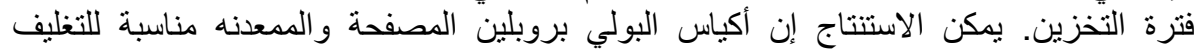

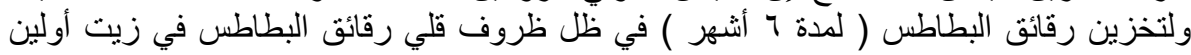


Egyptian J. of Nutrition Vol. XXXVI No. 1 (2021)

الكلمات المفتاحية: البطاطس ؛ البولي بروبلين ؛ الثد ؛ النفاذية ؛الجودة ؛ الخصائص السطح 